\title{
Factors Determinant Anemia Events in Pregnant Woman in Puskesmas Pesantren I Kediri City
}

\author{
Ira Nurdiana ${ }^{1}$, \\ Nurwijayanti ${ }^{2}$, \\ Nurdina $^{2}$ \\ ${ }^{1}$ Magister of Health Study \\ Program of STIKes Surya Mitra \\ Husada Kediri \\ ${ }^{2}$ Lecturer of STIKes Surya Mitra \\ Husada Kediri \\ Email: \\ irachoirulsholeh@gmail.com
}

Received : October 4, 2018

Accepted : October 6, 2018

Published : November 30, 2018

\begin{abstract}
Anemia of pregnant women has an impact on the rate of morbidity and maternal mortality, increased morbidity and fetal mortality, and increased risk of LBW. The incidence of anemia is influenced by various factors, including diet, taboo food knowledge, and compliance of $\mathrm{Fe}$ tablets. The purpose of this study is to analyze the effect of anemia on pregnant women at Pesantren 1 Health Center of Kediri. The research design used is quantitative research using cross sectional approach. The sampling technique used was simple random sampling with sample of 63 respondents of pregnant women at Pesantren 1 Health Center of Kediri. Data analysis technique used logistic regression test. The result of research showed that from 63 respondents, $32(50,8 \%)$ respondents had bad eating pattern having anemia, as many as $25(39,7 \%)$ respondents had poor taboo knowledge, 46\%) respondents are less adherent in consuming $\mathrm{Fe}$ tablet so that anemia. The results of analysis using logistic regression test showed significance value of $0.000<(\alpha=0.05)$, meaning $\mathrm{H} 0$ rejected and $\mathrm{H} 1$ accepted, this means that there is influence of diet, taboo food knowledge, compliance drinking Fe tablet with the incidence of anemia. The most dominant factor affecting the incidence of anemia is adherence $(\alpha=0,000 \mathrm{OR}=45,379)$. Diet, taboo food knowledge and adherence affects the incidence of anemia by $91 \%$ and the incidence of anemia in pregnant women is affected by other factors by $9 \%$. Pregnant women who have poor adherence to consuming Fe tablets have anemia. One of the efforts to reduce anemia is with a good diet, increased knowledge of pregnant women and motivate mothers to obediently take tablets.
\end{abstract}

Keywords: Anemia, compliance drink tablet fe, tabuits food knowledge, diet

Copyright (C) 2018 STIKes Surya Mitra Husada All right reserved.

This is an open-acces article distributed under the terms of the Creative Commons Attribution-ShareAlike 4.0 International License.

\section{INTRODUCTION}

Pregnancy is a process that begins with the release of mature egg cells that meet the sperm, both together and form the cells that will grow (BKKBN, 2017). Pregnancy is a process that begins with the release of mature egg cells that meet the sperm, both together and form the cells that will grow (BKKBN, 2017). In this second trimester pregnancy, pregnant women often experience swelling of the legs. This can be overcome by reducing the consumption of foods containing sodium and chloride ions (BKKBN, 2015). Additional energy during trisemester II is necessary for the expansion of maternal tissue such as the addition of blood volume, uterine and breast growth, and fat 
accumulation. During trisemester III additional energy is used for fetal and placental growth (Smitht et al, 2013).

Anemia is a deficiency of iron commonly afflicted by pregnant women. Basically anemia is a rational problem and has an enormous influence on human resources. Anemia is the world's second leading cause of disability and one of the most serious global public health issues (WHO, 2014). According Soedjatmiko, if since adolescence anemi during pregnancy and childbirth will follow anemi. Iron is very important for brain development. As a result will be born infants with below average intelligence (Kompas, 2015). Anemia is one form of nutritional problems in Indonesian society, food and nutrition are closely related, because one's nutrient is affected by the food conditions consumed. Food problems include food availability and food consumption insecurity influenced by poverty, low education, and customary beliefs associated with food taboos (Baliwati, Dwiriani, 2014)

\section{MATERIALS AND RESEARCH METHODS}

\section{Research design}

The design of this research is analytical observation with cross sectional approach that is a research approach to see a relationship between several variables measured simultaneously and only one measurement or observation without any follow-up.

The study measures the independent variables (diet, taboo food knowledge, adherence) and the dependent variable (incidence of anemia in pregnant women) simultaneously when the researchers met pregnant women at Pesantren 1 Puskesmas.

\section{Research time}

This research was conducted on February 5-24, 2018 at Puskesmas Pesantren 1 Kota Kediri.

\section{Variables}

The independent variable is the causal variable or independent variable. Independent variables in this study are diet, taboo food knowledge and compliance drinking Fe tablets. The dependent variable is a dependent variable or an output variable. Dependent variable in this research is incidence of anemia in pregnant mother.

\section{Materials Research Subjects Or Research}

\section{Materials}

\section{Population}

The target population inclusion criteria in this study were pregnant women who were willing to be the respondents of the study, the age of pregnancy trisemester I - III and pregnant women who are (domiciled) in the work area of Pesantren I Health Center Pesantren Kediri, pregnant women who visited Puskesmas Pesantren I Kediri City. The number of population of pregnant women in each month who visited the Community Health Center Pesantren I Kediri average as many as 75 pregnant women. 


\section{Sample}

The sample size in this study was calculated using the following formula:

$$
\begin{aligned}
& \mathrm{n}=\text { sample size } \\
& \mathrm{N}=\text { large population } \\
& \mathrm{a}=\text { error value }
\end{aligned}
$$

With a large population of 75 pregnant women, the sample size on this thesis proposal can be calculated as follows:

$$
\begin{aligned}
& n=\frac{\mathrm{N}}{\left(1+\left(\mathrm{N} \times a^{2}\right)\right.} \\
& n=\frac{75}{\left(1+\left(75 \times 0,05^{2}\right)\right)} \\
& n=\frac{75}{1,1875} \\
& n=63 \text { respondents }
\end{aligned}
$$

\section{Sampling Technique}

This research uses simple random sampling technique that is sampling technique from target population by taking randomly. In this study, the number of sample subjects 63 pregnant women in UPTD Puskesmas Pesantren 1 Kediri City.

\section{Instrument}

In collecting the data, the researcher used questionnaire as the instrument, which was developed with Likert scale approach. Variable diet pattern, taboo food knowledge using Likert scale approach for the variable of Fe tablet drink compliance using pill count method, and the occurrence of anemia using cyanmethemoglobin method. Before the research tool used in the first tested the validity test for reliability test

\section{Data analysis}

To determine what factors influence the incidence of anemia in pregnant women trisemester II ordinal logistic regression test with $\alpha=0,05$. Together all independent variables tested with dependent variable using ordinal logistic regression test to know which independent variables have influence and the most influential to the dependent variable.

\section{RESULTS}

To know the factors that influence the incidence of anemia in pregnant women at Pesantren I Health Center Kediri, tested using statistical test regression logistic, using SPSS for Windows version 21.0. The results of the analysis are as follows: 


\section{Model Fitting Information}

Table 1. Test Results Model Fitting Information

\begin{tabular}{ccccc}
\hline \multicolumn{4}{c}{ Model Fitting Information } & \\
\hline \multirow{2}{*}{ Model } & Model Fitting Criteria & \multicolumn{2}{c}{ Likelihood Ratio Tests } & \\
\cline { 2 - 5 } & -2 Log Likelihood & Chi-Square & df & Sig. \\
\hline Intercept Only & 80,917 & & & \\
\hline Final & 9,516 & 71,400 & 5 &, 000 \\
\hline
\end{tabular}

Source: Primary data of research in 2017

Results of statistical tests to pregnant women at Pesantren I Kediri City Health Center using a degree of error of 0.05 obtained $p$ value of 0.000 . If $p$ value <degree of error then there is influence between dietary variables, taboo food knowledge and adherence to the incidence of anemia in pregnant women at Pesantren I Health Center Kediri.

Tabel 2. Pseudo R-Square test results

\begin{tabular}{lr}
\hline & Pseudo R-Square \\
\hline Cox and Snell &, 678 \\
\hline Nagelkerke &, 910 \\
\hline McFadden &, 830 \\
\hline
\end{tabular}

The results of statistical test in this study obtained value Pseudo R-Square at Nagelkerke of 0.910 this means diet, taboo food knowledge and compliance affect the incidence of anemia in pregnant women by $91.0 \%$ and the rest influenced by other factors by $9 \%$

\section{Effect of Dietary Factor with Pregnancy Anemia}

To determine the effect of dietary factors with the incidence of anemia of pregnant women, used statistical test logistic regression with the following results:

Table 3. The results of statistical test of the influence of diet with anemia incidence of pregnant women in UPTD Puskesmas Pesantren 1 Kota Kediri

\begin{tabular}{|l|l|r|r|r|r|r|r|}
\hline \multicolumn{2}{|c|}{} & \multicolumn{1}{|c|}{ B } & \multicolumn{1}{c|}{ S.E. } & \multicolumn{1}{|c|}{ Wald } & \multicolumn{1}{c|}{ df } & \multicolumn{1}{c|}{ Sig. } & Exp(B) \\
\hline \multirow{2}{*}{ Step 1 } & Pola_Makan & 4,605 &, 906 & 25,824 & 1 &, 000 & 100,000 \\
\cline { 2 - 8 } & Constant & $-1,833$ &, 539 & 11,581 & 1 &, 001 &, 160 \\
\hline
\end{tabular}

Based on table 3 it is known that p-value $=0,000$, which means $<0.05$, so $\mathrm{H} 1$ is accepted. Thus on the bivariate test it is known that there is an influence between diet with anemia incidence of pregnant women in UPTD Puskesmas Pesantren 1 Kediri City. 


\section{The Influence of Food Stress Knowledge Factor with Pregnancy Anemia}

To know the influence of food knowledge factors taboo with the incidence of anemia of pregnant women, used statistical test logistic regressi with result as follows:

Table 4. Statistical results of the influence of taboo food knowledge with the incidence of anemia of pregnant women in UPTD Puskesmas Pesantren 1 Kota Kediri

\begin{tabular}{|l|l|r|r|r|r|r|r}
\hline \multicolumn{2}{|c|}{} & \multicolumn{1}{c|}{ B } & \multicolumn{1}{c|}{ S.E. } & Wald & df & \multicolumn{1}{c}{ Sig. } & \multicolumn{1}{c}{ Exp(B) } \\
\hline \multirow{2}{*}{ Step 1a } & $\begin{array}{l}\text { Makanan_T } \\
\text { abu }\end{array}$ & 3,884 & 1,028 & 14,266 & 1 &, 000 & 48,597 \\
\cline { 2 - 8 } & Constant & $-7,260$ & 2,030 & 12,786 & 1 &, 000 &, 001 \\
\hline
\end{tabular}

Based on table 4 it is known that p-value $=0,000$, which means $<0.05$, so $\mathrm{H} 2$ is accepted. Thus in bivariate test known that there is influence between taboo food knowledge with the incidence of anemia of pregnant women in UPTD Puskesmas Pesantren 1 Kota Kediri

\section{Influence of Compliance Factors with Pregnancy Anemia}

To know the influence of adherence factor with the incidence of anemia of pregnant mother, used statistic test logistic regressi with result as follows

Table 5. Statistical results of the effect of adherence to the incidence of maternal anemia in UPTD Puskesmas Pesantren 1 Kota Kediri

\begin{tabular}{|l|l|r|r|r|r|r|r|}
\hline \multicolumn{2}{|c|}{} & \multicolumn{1}{c|}{ B } & \multicolumn{1}{c|}{ S.E. } & \multicolumn{1}{c|}{ Wald } & \multicolumn{1}{c|}{ df } & \multicolumn{1}{c|}{ Sig. } & \multicolumn{1}{c|}{$\operatorname{Exp(B)}$} \\
\hline \multirow{2}{*}{ Step 1a } & Kepatuhan & 4,410 & 1,096 & 16,195 & 1 &, 000 & 82,293 \\
\cline { 2 - 8 } & Constant & $-9,831$ & 2,391 & 16,910 & 1 &, 000 &, 000 \\
\hline
\end{tabular}

Based on table 5 it is known that $\mathrm{p}$-value $=0,000$, which means $<0.05$, so $\mathrm{H} 3$ is accepted. Thus in bivariate test known that there is influence between adherence to the incidence of anemia of pregnant women in UPTD Puskesmas Pesantren 1 Kota Kediri

\section{The Most Dominant Factors Influencing Pregnancy Anemia}

To determine the most dominant factors that affect the incidence of maternal anemia, used statistical test of logistic regression follows:

Table 6. The result of statistical test of logistic regression of the influence of diet, taboo food knowledge and adherence to the incidence of anemia of pregnant women at UPTD Puskesmas Pesantren 1 Kota Kediri 


\begin{tabular}{|r|l|r|r|r|r|r|r|}
\hline \multicolumn{2}{|c|}{} & \multicolumn{1}{c|}{ B } & \multicolumn{1}{c|}{ S.E. } & Wald & df & Sig- & Exp(B) \\
\hline \multirow{3}{*}{ Step 1 } & Pola_Makan & 3,386 & 1,562 & 4,696 & 1 &, 030 & 29,545 \\
\cline { 2 - 8 } & Makanan Tabu & 2,879 & 1,402 & 4,215 & 1 &, 040 & 17,801 \\
\cline { 2 - 8 } & Kepatuhan & 3,815 & 1,725 & 4,892 & 1 &, 027 & 45,379 \\
\cline { 2 - 8 } & Constant & $-15,019$ & 5,171 & 8,436 & 1 &, 004 &, 000 \\
\hline
\end{tabular}

From the statistical test of logistic regression, $p$-value on the dietary factor $p=0,030<0,05$, $\mathrm{H} 1$ was accepted, the taboo food knowledge factor $\mathrm{p}=0,040<0,05, \mathrm{H} 2$ was accepted, and on the adherence factor $\mathrm{p}=0.027<0.05$, then $\mathrm{H} 3$ is accepted. Thus it is known that diet, taboo food knowledge and adherence are factors that affect the incidence of maternal anemia.

The magnitude of influence is shown by the value of EXP (B) or also called ODDS RATIO (OR). Variable X1 (diet) with OR 29,545, while variable X2 (taboo food knowledge) with OR 17,801 and variable X3 (adherence) show OR equal to 45,379. Based on these results OR or the magnitude of the greatest or dominant influence lies in the variable X3 with large OR 45,379. So it can be concluded that the most dominant factor affecting Y (the incidence of anemia of pregnant women) is maternity compliance factor in consuming Fe tableat, with the influence of 45,379.

\section{DISCUSSION}

Improve a healthy diet that contains iron from food. Eating a wide variety of nutrient-rich foods including vitamins can increase iron absorption, such as vitamin C. Changing dietary habits and clean living. The level of knowledge of taboo foods influences his behavior, the high level of education or knowledge, the higher the awareness to prevent anemia. Iron supplementation is beneficial because it can improve the status of hemoglobin in a relatively short time. The nutritional needs of pregnant women increase during pregnancy. Nutrition is used by mother and baby. Most needed is the need for iron, if the mother lacks the substance the pregnant mother suffers from anemia. For that, in addition to attention to a good diet, pregnant women should drink regular $\mathrm{Fe}$ tablet so that iron needs during pregnancy can be met. Efforts to improve the nutrition of pregnant women in order to avoid anemia, pregnant women need to consume nutrients from a good diet, increase knowledge of nutritional and nutritional needs during pregnancy, taking regular Fe tablets.

\section{CONCLUSION}

There is influence of pregnant woman's diet against the incidence of anemia at Pesantren 1 Health Center Kediri. There is a significant correlation between diet with age, occupation, education and compliance drinking Fe tablet with incidence of anemia of pregnant mother at Pesantren 1 Health Center of Kediri City. There is influence of maternal obedience to the incidence of anemia in pregnant women at Pesantren I Health Center Kediri. Disobedience bu pregnant drinking tablet Fe, caused no discipline in drinking it, refused because it resulted in nausea. Results of statistical tests to pregnant women at Pesantren I Kediri City Health Center using a degree of error of 0.05 obtained p value of 0.000 . If $\mathrm{p}$ value < degree of error then there is influence between dietary variables, taboos food knowledge and adherence to the incidence of anemia in pregnant women at Pesantren I Health Center Kediri. The most dominant factor affecting Y (morbidity of anemia of pregnant mother) is maternity compliance factor in consuming Fe tableat, with influence of 45,379. 


\section{BIBLIOGRAPHY}

Alimul. (2013). Metode Penelitian dan Keperawatan \& Tehnik Analisa Data. Jakarta: Salemba Medika.

Ambarwati, Eny Retna. (2012). Asuhan Kebidanan Nifas. Jogjakarta: Nuha Medika.

Azwar, Saifuddin. (2011). Reliabilitas dan Validitas. Yogyakarta: Pustaka Pelajar.

Departemen kesehatan RI. (2011). Rencana Strategis Dinas Kesehatan Provinsi Jatim Tahun 2009 - 2014.

Depkes, (2014). Profile Kesehatan Indonesia. Diunduh pada $10 \quad$ Pebruari 2017 dari www.depes.go.id/download/pusdatin.

Depkes RI. (2011). Diakses pada 13 September 2017 dari http://www.gizikia.depkes.go.id/archives/658.

Dewi, Vivian Nanny lia. (2011). Asuhan Kebidanan Pada Ibu Hamil. Jakarta: Salemba Medika.

Dinas Kesehatan Provinsi Jawa Timur, seksi, gizi. (2013). Data Capaian Program Gizi.

Dinkes Prov. (2015). Profil kesehatan provinsi jatim: Badan penerbit Dinkes Prov Jatim.

Friedman, M., Bowdn, U.r., \& Jones, E.G. (2010). Buku Ajar Keperawatan Keluarga: riset, teori dan praktik. Jakarta: EGC.

Kemenkes RI. (2011). Profil Kesehatan Indonesia 2010. Jakarta: Kementrian Kesehatan RI.Online.Http://www.depkes.go.id/resuuces/download/pusdatin, profil kesehatan - indonesia/profil-kesehatanindonesia-2010-pdfKemenkes RI 2014. Pusat data Dan Informasi.

Mardiwiono. (2009). Hubungan Tingkat Pengetahuan Ibu Hamil Tentang Anemia Dengan Status Anemia dalam Kehamilan di Puskesmas Kalibawang. Artikel Kesehatan.

Notoatmodjo. S. Promosi Kesehatan dan Ilmu Perilaku. (2012). Jakarta: Rieneka.

Nursalam. (2014). Manajemen Keperawatan: Aplikasi dalam Praktek Keperawatan Profesional edisi 4. Jakarta: Salemba Medika.

Patimah. (2015). pola konsumsi ibu hamil dan hubungannya dengan kejadian anemia Defisiensi Besi pada Ibu Hamil, J. Sains \& Teknologi, Desember 2017, Vol 7 No 3.

Poon. Kky, (2011). Does in hospital breastfeeding self efficacy predict breastfeeding duration. Fheesis of master of science, departement of community. Health and epidemiology, dueen's university, Q S space, kingston, otario, canada.

Prasetyono, D. (2011). Buku Pintar ASI Eksklusif, Pengenalan Praktek dan Kemanfaatannya, Yogyakarta: Diva press. Pusat data dan informasi kementrian kesehatan. RI-jakarta: 2013.

Rahmanto. (2011). Minat Kerja Mahasiswa Program Studi Pendidikan Teknologi Argoidustri Universitas Pendidikan Indonesia, diunduh dari www.minat./tanggal 8/11/2017.

Saryono. (2011). Metodologi Penelitian Kesehatan Yogyakarta: mitra cendikia.

Sujarweni, wiratna. (2014). Metodologi Penelitian: lengkap, Praktis dan mudah dipahami. Yogyakarta: PT Pustaka baru.

Sulistiyawati, A. (2011). Buku Ajar Asuhan Kebidanan Pada Ibu hamil. Yogyakarta: Penerbit Andi

Suparyanto. (2010). Konsepparitas/partus. Edisi online. Http://dr. Suparyanto blogspot.co.id/2010-/10/konseppartus. 
Unicef. (2013). Breastfeeding. Is The Cheapest and most effective life - saver in history. Press veelase. Di unduh dari : http://www.unicef.org/tanggal 20 september 2017.

WHO. (2014). Nutrition, exclusive Breastfeeding, di unduh dari :http://www.who.int/ tanggal 12 nopember 2017.

Zulaikhah. (2015). Hubungan pola makan dengan kejadian anemia pada ibu Hamil Trisemester III di Puskesmas Pleret Bantul Tahun 2015. 